\title{
LITERASI DALAM TEKS REKAMAN PERCOBAAN SISWA KELAS IX SMP
}

\author{
Afiyah Nur Kayati \\ Universitas Trunojoyo Madura, Jalan Raya Telang, Bangkalan \\ Email: Afiyahkay2@gmail.com
}

\begin{abstract}
Abstrak
Literasi merupakan kemampuan membaca kemudian berpikir dan selanjutnya diaktualisasikan dengan menulis. Literasi dalam teks rekaman percobaan siswa kelas IX SMP terdiri atas literasi sebagai praksis lingual dan literasi sebagai praksis kelogisan berikir. Literasi sebagai prakis lingual ditunjukkan dengan kelengkapan dan keruntuntutan struktur teks rekaman percobaan yang ditulis serta penggunaan istilah ilmiah dalam teks rekaman percobaan yang ditulis siswa. Sedangkan, literasi sebagai praksis berpikir ditunjukkan dengan model pengembangan paragraf definisi dan teknik berpikir sistematis yang tampak pada penulisan prosedur kerja.
\end{abstract}

Kata kunci : literasi, teks rekaman percobaan, praksis lingual, praksis kelogisan berpikir

\begin{abstract}
Literacy is the ability to read then think and then actualized by writing. Literacy in the text of the experimental experiment of junior high school class IX students consists of literacy as a lingual praxis and literacy as a logical praxis of thinking. Literacy as a lingual praxis is indicated by the completeness and consistency of the structure of the recorded text of the experiment written as well as the use of scientific terms in the text of the experiment written by students. Whereas, literacy as a praxis of thinking is shown by the model of developing paragraph definitions and systematic thinking techniques that appear in writing work procedures.
\end{abstract}

Keywords: literacy, experimental record texts, lingual praxis, logical thinking praxis

\section{Pendahuluan}

Keterampilan berbahasa dapat digolongkan menjadi keterapilan reseptif dan produktif. Keterampilan reseptif meliputi keterampilan menyimak dan membaca, sedangkan keterampilan produktif meliputi keterampilan berbicara dan menulis. Keterampilan tersebut harus dikuasai oleh peserta didik dalam pembelajaran bahasa Indonesia.

Kegiatan menulis merupakan salah satu aktivitas yang selalu dilaksanakan oleh semua jenjang pendidikan sebagai bahan pembelajaran. Menulis merupakan suatu proses pengolahan ide atau gagasan ke dalam bentuk tulisan. Tulisan sebagai hasil pemikiran tidak lepas dari kondisi sosial budaya penulis. Kondisi sosial budaya tersebut termasuk ilmu pengetahuan dan teknologi yang dikuasai penulis. Ilmu pengetahuan dan teknologi ini dapat dipelajari dengan penggunaan penguasaan literasi (keaksaraan dan kewicaraan) yang memadai. Oleh karena itu, literasi ini menjadi kebutuhan pendidik dan peserta didik.
Literacy erat kaitannya dengan istilah kemahirwacanaan. Literasi secara luas dimaknai sebagai kemampuan berbahasa yang mencakup kemampuan menyimak, berbicara, membaca, dan menulis, serta kemampuan berpikir yang menjadi elemen di dalamnya. Menurut UNESCO (dalam Wiedarti, 2016:7) literasi juga bermakna praktik dan hubungan sosial yang terkait dengan pengetahuan, bahasa, dan budaya.

Eanes (1995:2) mengemukakan literasi adalah penggunaan membaca dan menulis, dan berpikir kritis sebagai komunikasi dan alat belajar. Dalam proses itu, menulis adalah hasil dari membaca kritis. Menulis ialah sebuah proses menciptakan teks. Penulis mengendapkan teks bacaan dalam dirinya, lalu membandingkannya dengan fenomena sosial di sekitarnya sehingga terjadi proses penciptaan teks. Dengan demikian, kegitan menulis bukan hanya merupakan proses kontruksi, tetapi juga reproduksi dan kreativitas peserta didik dalam berbahasa reseptif maupun produktif. Kesimpulan ini yang digunakan untuk 


\section{Volume 4 No. 1 METALINGUA}

April 2019 Jurnal Pendidikan Bahasa dan Sastra Indonesia

menganalisis literasi dalam penulisan teks rekaman percobaan siswa.

Dalam konteks globalisasi yang menjadi kecenderungan masyarakat modern, pembelajaran bahasa Indonesia harus diorientasikan pada pemahaman mendalam dan pemroduksian tes lisan dan teks tulis bahasa Indonesia bernuansa global. Salah satu pendekatan yang relevan dengan orientasi pembelajaran bahasa Indonesia itu adalah pendekatan literasi. Pendekatan literasi dengan konteks pembelajaran bahasa Indonesia dapat dicermati dari tujuh prinsip pendekatan literasi yang diuraikan oleh Kern (dalam Sodiq, 2010:88), yaitu (a) interpretasi yang bermaksud bahwa penulis dan pembaca diasumsikan terlibat dalam tindak ganda yakni penulis menginterpretasi dunia (peritiwa, pengalaman, gagasan) dan pembaca menginterpretasikan interpretasi penulis berdasarkan konsep atau pemahamannya sendiri tentang dunia; (b) kolaborasi yang bermaksud bahwa penulis menulis untuk sebuah khalayak pembacanya yang kemudian pembaca memberi motivasi, pengetahuan, dan pengalaman agar teks yang ditulis penulis tersebt bermakna; (c) aturan yang bermaksud bahwa cara orang membaca dan menulis teks dikedalikan oleh aturan atau konvensi budaya; (d) pengetahuan budaya yang bermaksud bahwa membaca dan menulis berfungsi di dalam sistem sikap, kepercayaan, kebiasaan, cita-cita, dan nilai-nilai tertentu; (e) pemecahan masalah yang bermaksud bahwa membaca dan menulis melibatkan usaha pemahaman hubungan antara kata, makna yang lebh besar, teks, dan dunia nyata; (f) refleksi yang bermaksud bahwa pembaca dan penulis memikirkan bahasa dalam hubungannya dengan dunia dan dengan diri mereka masing-masing; dan $(\mathrm{g})$ penggunaan bahasa yang bermaksud bahwa literasi memerlukan penggunaan bahasa dalam konteks lisan dan tulis untuk menciptakan teks dan bukan hanya sistem menulis atau sekadar pengetahuan kebahasaan.

Dari hal tersebut literasi erat dengan praksis lingual, praksis kelogisan berpikir, dan praksis konteks sosial. Literasi sebagai praksis lingual merupakan kemampuan menggunakan bahasa sebagai ungkapan pada tulisan yang mencakup penataan struktur tematik berpikir yang lengkap. Satuan lingual yang tertuang dalam teks bisa berupa kata, frasa, klausa dan kalimat. Literasi sebagai kelogisan berpikir dalam bahasa dan kemampuan berpikir didasarkan pada teori Piaget, bahwa berpikir diperoleh terlebih dahulu kemudian kemampuan berbahasa. Waddsworths (dalam Ellis, 1989:15) berpendapat bahwa hanya setelah mencapai kemampuan untuk mengekspresikan pengalaman secara internal anak-anak dapat memulai konstruksi kemampuan bahasa lisannya. Saat bahasa terkembangkan, perkembangan konseptual secara paralel akan terkembangkan. Dengan demikian, bahasa dan berpikir berasal dari pengalaman dan saling mendukung satu sama lain.

Pembelajaran bahasa Indonesia dalam K13 menggunakan pembelajaran berbasis teks. Teks dapat berwujud tertulis atau pun lisan. Teks merupakan ungapan pikiran manusia yang lengkap yang di dalamnya memiliki situasi dan konteks. Teks dapat dikelompokkan ke dalam teks cerita, teks faktual, dan teks tanggapan. Sesuai dengan Kurikulum 2013, salah satu teks faktual yang diajarkan di SMP adalah teks rekaman percobaan.

Teks rekaman percobaan adalah teks yang memaparkan laporan hasil percobaan atau penelitian yang dapat dipertanggungjawabkan kebenarannya secara keilmuan. Teks rekaman percobaan harus disusun dengan menggunakan struktur dan fitur bahasa yang sesuai dengan kaidah keilmuan. Struktur teks rekaman percobaan terdiri dari tujuh bagian, yaitu judul, pendahuluan, landasan teori atau kajian pustaka, metode penelitian, hasil dan pembahasan, simpulan, dan daftar pustaka (Wahono, 2013:108).

Dalam menulis teks rekaman percobaan, peserta didik harus bisa mengolah informasi yang dia baca untuk diterapkan dalam sebuah percobaan sederhana yang kemudian harus disusun laporannya. Dalam pembelajaran ini peserta didik harus banyak membaca agar bisa menerapkan teori sesuai dengan tema atau topik percobaan yang dilakukan. Dengan demikian melalui pembelajaran teks rekaman percobaan ini, peserta didik dapat berliterasi melalui kegiatan membaca dan menulis. Dari hasil tulisan teks rekaman percobaan tersebut, akan terlihat sejauh mana kemampuan literasi peserta didik tersebut.

Adapun tujuan penelitian ini adalah 1) mendeskripsikan literasi sebagai praksis lingual dalam teks rekaman percobaan siswa kelas IX SMP dan 2) mendeskripsikan literasi sebagai praksis kelogisan berpikir dalam teks rekaman percobaan siswa kelas IX SMP. 


\section{Metode Penelitian}

Penelitian ini merupakan penelitian kualitatif karena sumber data dalam penelitian ini adalah hasil produk bahasa yang berupa teks rekaman percobaan. Sumber data dalam penelitian ini adalah teks rekaman percobaan siswa kelas IX D MTs Unggulan Amanatul Ummah yang berjumlah 20 siswa. Pemilihan keals IX D sebagai subjek penelitian dilakukan secara random. Teknik pengumpulan data yang digunakan dalam penelitian ini adalah teknik penugasan. Siswa diberi tugas untuk menyusun teks rekaman percobaan. Teks rekaman percobaan siswa berupa dokumen teks tertulis dalam bentuk lembar kerja atau fortofolio. Instrumen yang digunakan dalam pengumpulan data penelitian ini adalah lembar petunjuk penulisan teks rekaman percobaan untuk siswa.

Data dalam penelitian ini dianalisis menggunakan metode agih. Metode tersebut adalah metode analisis yang alat penentunya adalah unsur bahasa yang ada di dalam bahasa, bahkan menyatu dengan datanya. Teknik yang digunakan dalam analisis data penelitian ini adalah teknik bagi unsur langsung. Teknik bagi unsur langsung adalah teknik analisis data dengan cara membagi suatu konstruksi menjadi beberapa bagian atau unsur-unsur itu dipandang sebagai bagian atau unsur yang langsung membentuk konstruksi. Alat penentu teknik bagi unsur langsung adalah intuisi kebahasaan peneliti terhadap bahasa yang diteliti. Pengecekan keabsahan data dalam penelitian ini dilakukan dengan menggunakan teknik ketekunan pengamatan, triangulasi data, dan pengecekan teman sejawat.

\section{Hasil Dan Pembahasan}

\section{Literasi Sebagai Praksis Lingual dalam} Teks Rekaman Percobaan Kelas IX SMP

Literasi sebagai praksis lingual dalam teks rekaman percobaan siswa kelas IX SMP diungkapkan dalam pola penataan struktur yang di dalamnya meliputi judul; pendahuluan yang terdiri atas latar belakang, rumusan masalah, dan tujuan; landasan terori; metode penelitian; hasil dan pembahasan; simpulan; dan daftar pustaka. Selain struktur dalam teks rekaman percobaan juga terdapat kaidah kebahasaan. Dalam penulisan teks rekaman percobaan, kaidah kebahasaan meliputi kata ilmiah, penulisan daftar pustaka, dan kalimat efektif yang kohesif dan koherensi.

\section{a. Literasi yang Dinyatakan dalam Pendahuluan pada Teks Rekaman Percobaan Siswa Kelas IX SMP}

Pendahuluan dalam teks rekaman percobaan siswa kelas IX SMP digunakan sebagai pemaparan latar belakang, rumusan masalah, dan tujuan percobaan secara lengkap. Dalam pendahuluan tingkat kemampuan literasi siswa terutama dapat dilihat dalam bagian latar belakang. Hal itu dikarenakan dalam latar belakang akan tampak pemikiran siswa tentang alasan melakukan percobaan tersebut.

Pendahuluan dalam teks rekaman percobaan tersebut menggunakan teknik berpikir definisi dengan mengembangkan paragraf yang berisi pernyataan umum tentang tema percobaan yang dilakukan kemudian ke hal-hal yang lebih khusus. Literasi yang dinyatakan dalam pendahuluan dalam teks rekaman percobaan tersebut tampak pada data berikut.

(01)

(a) Secara umum sosis adalah makanan instan yang sering dikonsumsi masyarakat luas. Biasanya sosis terbuat dari daging ayam, kambing, sapi, dan lainnya. Sosis merupakan pilihan cepat yang biasanya diambil oleh para ibu rumah tangga dan anak-anak. Hal itu dikarenakan sosis memiliki rasa yang enak dan kemasan yang praktis.

(b) Makanan instan seperti itu belum tentu mengandung zat yang diperlukan bagi tubuh. Makanan tersebut mengandung zat berbahaya yang dapat merusak tubuh, apalagi setelah meminum minuman bersoda.

(c) Setelah sosis dikonsumsi dengan minuman bersoda sosis akan mengeluarkan zat yang dapat membahayakan tubuh, seperti mikroba kecil. Berdasarkan hal tersebut, maka perlu dilakukan pengujian tentang zat yang keluar dari sosis setelah direndam dengan air soda.

Latar belakang teks remakan percobaan dapat dilihat pada data (01). Latar belakang tersebut disusun dengan menuliskan hal yang umum terlebih dahulu, yaitu tentang sosis, kemudian tentang kandungan sosis dan reaksi yang ditimbulkan apabila dikonsumsi bersama 
soda. Penggunaan konjungsi antar kalimat juga terdapat pada data (01) di atas, yaitu berdasarkan hal tersebut sehingga paragraph yang dihasilkan menjadi paragraph yang kohesif dan selanjutnya koherensi.

Data (01) dapat mengalami perubahan pola penulisan dan menjadi kurang berterima jika paragraf pertama, yaitu bagian (a) pada data tersebut dilesapkan. Data pada (01) akan menjadi seperti data berikut.

(01a)

(a) Makanan instan seperti itu belum tentu mengandung zat yang diperlukan bagi tubuh. Makanan tersebut mengandung zat berbahaya yang dapat merusak tubuh, apalagi setelah meminum minuman bersoda.

(b) Setelah sosis dikonsumsi dengan minuman bersoda sosis akan mengeluarkan zat yang dapat membahayakan tubuh, seperti mikroba kecil. Berdasarkan hal tersebut, maka perlu dilakukan pengujian tentang zat yang keluar dari sosis setelah direndam dengan air soda.

Data pada (01a) menjadi kurang berterima karena tidak memiliki pernyataan yang bersifat umum. Latar belakang tersebut menuliskan tentang makanan instan yang tidak diketahui merujuk pada makanan apa.

b. Literasi yang Dinyatakan dalam Kajian Teori pada Teks Rekaman Percobaan Siswa Kelas IX SMP

Kajian teori dalam teks rekaman percobaan pada siswa kelas IX MTs Unggulan Amanatul Ummah disusun sesuai dengan teori yang dapat mendukung percobaan itu. Hal itu tampak pada data berikut.

(02)

(a) Uji coba adalah pengujian sesuatu sebelum digunakan.

(b) Mikroba adalah segala jasad hidup yang berukuran kecil.

(c) Zat pada sosis adalah bahan-bahan atau komposisi yang terkandung di dalam sosis baik itu zat berbahaya maupun yang menyehatkan tubuh.

Kajian teori pada teks rekaman percobaan siswa kelas IX SMP tersebut sudah sesuai dengan teori yang seharusnya digunakan dalam teks rekaman percobaan tersebut. Hal itu dikarenakan, kajian teori tersebut merupak teori yang sesuai dengan judul teks rekaman percobaan, yaitu Uji Kandungan Mikroba pada Sosis.

Data (02) dapat mengalami ketimpangan dengan judul apabila data pada bagian (c) diganti dengan data lain. Data pada bagian (c) diganti dengan "kandungan pada kentang". Data pada (02) akan menjadi seperti data berikut.

(02a)

(a) Uji coba adalah pengujian sesuatu sebelum digunakan.

(b) Mikroba adalah segala jasad hidup yang berukuran kecil.

(c) Kandungan pada kentang adalah zat yang terkandung dalam kentang, yaitu karbohidrat, glukosa.

Data pada (01a) menjadi tidak sesuai dengan tema atau percobaan yaitu uji kandungan mikroba dalam sosis.

c. Literasi yang Dinyatakan dalam Metode Penelitian pada Teks Rekaman Percobaan Siswa Kelas IX SMP

Metode penelitian dalam teks rekaman percobaan pada siswa kelas IX SMP berisi prosedur kerja yang disusun secara runtut sehingga percobaan tersebut berhasil. Prosedur kerja itu pun disusun secara detail dari langkah pertama sampai terakhir. Keruntutan pada penulisan prosedur tersebut membuat data prosedur penulisan itu kohesif satu sama lain sehingga menjadi koherensi. Keruntutan prosedur kerja dalam metode penelitian dalam teks rekaman percobaan pada siswa kelas IX MTs Unggulan Amanatul Ummah tampak pada data berikut.

(03)

\section{Prosedur Kerja}

(a) Siapkan gelas aqua, sosis, dan minuman bersoda!

(b) Masukkan sosis ke dalam gelas aqua!

(c) Tuangkan minuman bersoda sampai sosis terendam!

(d) Tunggu beberapa menit sampai pada permukaan sosis mulai bermunculan mikroba kecil!

Data pada (03) di atas akan menjadi tidak runtut jika beberapa bagian dalam prosedur kerja tersebut dibalik satu sama lain. Maka data prosedur kerja itu akan berubah mnjadi data berikut. 
(03a)

\section{Prosedur Kerja}

(a) Tunggu beberapa menit sampai pada permukaan sosis mulai bermunculan mikroba kecil!

(b) Masukkan sosis ke dalam gelas aqua!

(c) Tuangkan minuman bersoda sampai sosis terendam!

(d) Siapkan gelas aqua, sosis, dan minuman bersoda!

Data pada (03a) di atas berubah menjadi tidak runtut sebagaimana syarat penulisan prosedur kerja harus runtut. Data pada (03a) tersebut menjadi tidak berterima dan sulit untuk dipahami.

d. Literasi yang Dinyatakan dalam Daftar Pustaka pada Teks Rekaman Percobaan Siswa Kelas IX SMP

Penulisan daftar pustaka dalam teks rekaman percobaan pada siswa kelas IX SMP sudah sesuai dengan tata cara penulisan daftar pustaka, yaitu dengan cara nama pengarang dibalik dan diakhiri dengan tanda titik, diikuti dengan penulisan tahun dan diakhiri dengan tanda titik, dilanjutkan dengan penulisan judul buku dan ditulis miring serta diakhiri tanda titik, kemudian tempat terbit dan diakhiri dengan tanda titik dua, dan yang terakhir adalah nama penerbit. Penulisan daftar pustaka dalam teks rekaman percobaan pada siswa kelas IX SMP tersebut tampak pada data berikut.

(04)

Zubaidah, Siti. 2014. Ilmu Pengetahuan Alam. Jakarta: Kementrian Kebudayaan dan Pendidikan.

Data pada (04) akan berubah susunannya apabila digunakan teknik balik, yaitu dengan meletakkan judul pada bagian awal. Data pada (04) akan berubah menjadi data berikut.

(04a)

Ilmu Pengetahuan Alam. 2014. Zubaidah, Siti. Jakarta: Kementrian Kebudayaan dan Pendidikan.

Penulisan daftar pustaka pada data (04a) menjadi tidak berterima karena tidak sesuai dengan kaidah penulisan daftar pustaka. Hal itu menunjukkan bahwa dalam penulisan daftar pustaka dibutuhkan kemampuan literasi yang didapatkan dari proses membaca buku teks atau sumber bacaan lain yang berkaitan dengan daftar pustaka yang kemudian diaplikasikan dalam kegiatan menulis. Dalam penulisan daftar pustaka terlihat bahwa erdapat penerapan pengetahuan yang dimiliki siswa yang kemudian diakualisasikan dalam tulisan.

e. Literasi yang Dinyatakan dalam Kata Ilmiah pada Teks Rekaman Percobaan Siswa Kelas IX

Penggunaan kata-kata ilmiah dalam teks rekaman percobaan pada siswa kelas IX SMP terutama terlihat dalam kajian teori. Hal tersebut tampak pada data berikut.

(05)

Lemak merupakan senyawa organik yang tidak larut dalam air, tetapi larut dalam zat pelarut organik (nonpolar), seperti kloroform, eter, dan minyak tanah.

Pada data (05) tersebut terdapat kata-kata ilmiah atau istilah ilmiah, yaitu kloroform dan eter yang merupakan istilah dalam bidang biologi dan kimia. Kata-kata tersebut akan menjadi tidak ilmiah jika diganti dengan kata lain. Kata kloroform diganti dengan kata teh dan eter diganti dengan kopi. Maka data (05) akan berubah menjadi data berikut.

(05a)

Lemak merupakan senyawa organik yang tidak larut dalam air, tetapi larut dalam zat pelarut organik (nonpolar), seperti teh, kopi, dan minyak tanah.

Data (05a) tidak mengandung kata atau istilah ilmiah karena teh dan kopi merupakan kata yang digunakan dalam pergaulan seharihari. Sedangkan kata ilmiah adalah kata yang bersiat ilmu atau digunakan dalam ilmu tertentu.

\section{Literasi Sebagai Praksis Kelogisan Berpikir dalam Teks Rekaman Percobaan Kelas IX SMP}

Literasi sebagai praksis kelogisan berpikir terlihat dari teknik berpikir definisi dan berpikir sistematis. Pola pengembangan paragraf dengan teknik berpikir definisi lebih memberikan penjelasan atau pun keterangan terhadap istilah atau hal. Teknik berpikir sistematis menuliskan sesuatu secara berurutan yang digunakan dalam menulis prosedur kerja.

\section{a. Model Definisi dalam Teks Rekaman Percobaan Kelas IX SMP}

Pembahasan definisi menggunakan bahasa yang alami, sesuai dengan persyaratan definisi. Ada beberapa syarat pembahasan definisi yang telah disepakati. Pertama, definisi tidak boleh bersifat negatif; kedua, tidak boleh dibahasakan dengan pemarkah 
syarat; ketiga, definisi harus kongruen antara kelas istilah definiudum (nomina, verba, adjektifa); keempat, hubungan definiendum dengan definiens dimarkahi dengan ialah dan adalah dalam bahasa Indonesia. Definisi dalam teks rekaman percobaan siswa kelas IX SMP ditandai dengan kopula adalah. Kopula adalah tersebut menjelaskan tentang suatu hal yang akan didefinisikan. Definisi dalam teks rekaman percobaan tersebut tampak pada data berikut.

(06)

(a) Secara umum sosis adalah makanan instan yang sering dikonsumsi masyarakat luas. (b) Biasanya sosis terbuat dari daging ayam, kambing, sapi, dan lainnya. (c) Sosis merupakan pilihan cepat yang biasanya diambil oleh para ibu rumah tangga dan anak-anak. (d) Hal itu dikarenakan sosis memiliki rasa yang enak dan kemasan yang praktis.

Data (06) tersebut mendefinisikan sosis dengan menggunakan kopula adalah. Data (06) tersebut diawali dengan pernyataan umum kemudian dilanjutkan dengan kalimat penjelas. Pernyataan umum tersebut menuliskan bahwa sosis merupakan makanan instan yang sering dikonsumsi masyarakat luas. Kemudian diikuti dengan kalimat penjelas, yaitu kalimat yang menjelaskan tentang bahan-bahan sosis dan kemasan sosis.

Data (06) dapat mengalami perubahan pola definisi yang terkandung dalam teks rekaman percobaan siswa kelas IX SMP. Perubahan tersebut terjadi apabila dilakukan proses pelesapan. Pelesapan tersebt dilakukan pada data (06), yaitu pada kalimat (a) sehingga menghasilkan data berikut.

(06a)

(b) Biasanya sosis terbuat dari daging ayam, kambing, sapi, dan lainnya. (c) Sosis merupakan pilihan cepat yang biasanya diambil oleh para ibu rumah tangga dan anak-anak. (d) Hal itu dikarenakan sosis memiliki rasa yang enak dan kemasan yang praktis.

Hasil pelesapan kalimat (a) yang berisi tentang definisi banjir tampak pada konstruksi data (09a) yang berbeda dengan data (09). Pelesapan kalimat (a) pada data (09a) mengakibatkan hilangnya definisi yang terkandung dalam teks rekaman percobaan.

\section{b. Teknik Berpikir Sistematis dalam Teks Rekaman Percobaan Kelas IX SMP}

Teknik berpikir sistematis terlihat dalam metode penelitian dalam teks rekaman percobaan pada siswa kelas IX SMP yang berisi prosedur kerja yang disusun secara runtut sehingga percobaan tersebut berhasil. Keruntutan prosedur kerja dalam metode penelitian dalam teks rekaman percobaan pada siswa kelas IX SMP tampak pada data berikut.

(07)

(a) Siapkan gelas aqua, sosis, dan minuman bersoda!

(b) Masukkan sosis ke dalam gelas aqua!

(c) Tuangkan minuman bersoda sampai sosis terendam!

(d) Tunggu beberapa menit sampai pada permukaan sosis mulai bermunculan mikroba kecil!

Data pada (07) di atas akan menjadi tidak runtut jika beberapa bagian dalam prosedur kerja tersebut dibalik satu sama lain. Maka data prosedur kerja itu akan berubah menjadi data berikut

(07a)

\section{Prosedur Kerja}

(a) Tunggu beberapa menit sampai pada permukaan sosis mulai bermunculan mikroba kecil!

(b) Masukkan sosis ke dalam gelas aqua!

(c) Tuangkan minuman bersoda sampai sosis terendam!

(d) Siapkan gelas aqua, sosis, dan minuman bersoda!

Data pada (07a) di atas berubah menjadi tidak runtut sebagaimana syarat penulisan prosedur kerja harus runtut. Data pada (07a) tersebut menjadi tidak berterima dan sulit untuk dipahami.

\section{Simpulan}

Berdasarkan fokus dan tujuan penelitian yang diajukan, serta melalui penganalisisan data, maka dalam penelitian ini dapat ditarik simpulan berkaitan literasi dalam teks rekaman percobaan siswa kelas IX SMP. Pertama, literasi sebagai praksis lingual dalam teks rekaman percobaan didominasi dengan pola penataan struktur. Siswa dapat menulis teks rekaman percobaan sesuai dengan struktur teks rekaman percobaan. Dalam 
penyusunan latar belakang siswa menggunakan pola penyusunan dari umum ke khusus. Dalam bab metode siswa dapat menuliskan prosedur kerja secara runtut. Siswa juga dapat mengaplikasikan pengetahuannya tentang tata cara penulisan daftar pustaka dalam menuliskan daftar pustaka yang tepat. Kedua, literasi sebagai praksis kelogisan berpikir dalam teks rekaman percobaan siswa kelas IX SMP mencakup pola pengembangan pengembangan paragraf dengan teknik berpikir definisi dan teknik berpikir sistematis.

\section{Daftar Rujukan}

Akhadiah, Sabarti, dkk. 1998. Pembinaan Kemampuan Menulis Bahasa Indonesia. Jakarta: Erlangga.

Sodiq, Syamsul. 2010. Pengembangan Materi Pendidikan Kecakapan Hidup pada Buku Pelajaran Bahasa Indonesia dengan Model Literasi: Disertasi. Surabaya: Unesa.

Wahono, dkk. 2013. Mahir Berbahasa Indonesia untuk SMP/MTs Kelas IX. Jakarta: Erlangga.

Wiedarti, Pangesti, dkk. 2016. Desain Induk Gerakan Literasi di Sekolah. Jakarta: Direktorat Jenderal Pendidikan Dasar dan Menengah Kementrian Pendidikan dan Kebudayaan. 
Volume 4 No. 1 METALINGUA

April 2019 Jurnal Pendidikan Bahasa dan Sastra Indonesia 